\title{
BIOÉTICA E ENSINO DE CIÊNCIAS: O TRATAMENTO DE TEMAS CONTROVERSOS - DIFICULDADES APRESENTADAS POR FUTUROS PROFESSORES DE CIÊNCIAS E DE BIOLOGIA
}

\author{
Bioethics and science education: how to deal \\ with controversial themes - the difficulties \\ of future science and biology teachers
}

\author{
Paulo Fraga da Silva ${ }^{1}$ • Myriam Krasilchik ${ }^{2}$
}

\begin{abstract}
Resumo: O presente estudo tem como objetivo analisar como os licenciandos lidam com temas controversos que poderiam ser discutidos com seus futuros alunos, sobretudo a metodologia a ser utilizada em sala de aula. O percurso metodológico consistiu na aplicação e análise de um questionário com questões abertas, relacionadas a quatro casos com conteúdos dilemáticos aplicados a 32 licenciandos de Ciências e Biologia, pertencentes a três Instituições de Ensino Superior do município de São Paulo. Os dados apontaram que os licenciandos conseguem perceber conflitos éticos nos casos, porém não explicitam as estratégias de como abordá-los. Para os licenciandos, o professor tem um papel central, como expositor dos temas. Assim, a formação inicial pouco tem contribuído na instrumentalização dos futuros professores no exercício de tomada de posição e o convívio com a divergência. Destaca-se a importância da Bioética na socialização do debate científico e como um valioso instrumento metodológico no ensino de Ciências.

Palavras-chave: Ensino de Ciências. Ensino de Biologia. Bioética. Formação de professores. Temas controversos. Cidadania.
\end{abstract}

\begin{abstract}
The present study focused on analyzing how apprentice teachers deal with controversial themes which could be discussed with their students-to-be, and the methodological approach to be used in addressing them. The methodology consisted of the application and analysis of an openended questionnaire, related to four cases with controversial contents applied to 32 apprentice teachers of science and biology from three Universities in the city of São Paulo. The data showed that the apprentice teachers are able to notice ethical conflicts in the cases, although they do not explicit strategies on how to approach them. For them, the teacher has a central role as the one who exposes the themes. Thus, the initial training has not contributed in providing future teachers the ability to position themselves when dealing with differences of opinion. One should point out the importance of Bioethics in the scientific debate about socialization and its value as a methodological instrument in Science teaching.
\end{abstract}

Keywords: Science teaching. Biology teaching. Bioethics. Teacher formation. Controversial themes. Citizenship.

${ }^{1}$ Centro de Educação, Filosofia e Teologia (CEFT), Universidade Presbiteriana Mackenzie (UPM). Rua da Consolação, 896, prédio 25 (CEFT), São Paulo, SP, CEP 01302-907, Brasil. <paulo.silva1@mackenzie.br>

${ }^{2}$ Faculdade de Educação, Universidade de São Paulo (USP), São Paulo, SP, Brasil. 
Silva, P. F.; Krasilchik, M.

\section{Introdução}

As transformações sociais resultantes dos avanços da ciência e tecnologia têm sido objeto de discussão pelas implicações éticas que provocam. As produções científicas e tecnológicas estão sujeitas às forças que regem a sociedade, aos interesses econômicos, políticos, sociais, morais e éticos. Estão inseridas nos processos e valores sociais e criam preocupações que deveriam fazer parte do repertório do ensino das Ciências.

O presente trabalho considera a importância da Bioética para a socialização do debate científico como um valioso instrumento metodológico no ensino de Ciências, desencadeador de formas interdisciplinares de trabalhos pedagógicos.

Vale ressaltar que a Bioética tem recebido inúmeras definições. O termo Bioética poderia ser etimologicamente definido simplesmente como ética da vida (neologismo sobre as palavras gregas bio, vida, e ethike, ética). Outras definições são apresentadas no sentido de precisar melhor o termo. Uma delas, extraída da enciclopédia de Bioética, dá a ideia de seu caráter interdisciplinar: "Pode-se defini-la como sendo o estudo sistemático das dimensões morais - incluindo visão, decisão, conduta e normas morais - das ciências da vida e do cuidado da saúde, utilizando uma variedade de metodologias éticas num contexto interdisciplinar (REICH, 1995, p. 21).

A definição de Bioética adotada por este trabalho a considera como ética aplicada aos atos humanos, que podem ter consequências irreversíveis sobre os próprios homens ou sobre qualquer ser vivo (KOTTOW, 2003).

A educação em ciências não tem produzido resultados satisfatórios no que se refere, sobretudo, a uma preparação dos educandos para tomada de decisões. Há ainda uma forte resistência em considerar toda a sociedade como participante no desenvolvimento da Ciência (SILVA, 2002). Daí a importância de se investigarem as percepções, preocupações ou, mesmo, a preparação dos professores de Ciências e Biologia para lidarem com questões dilemáticas em sala de aula.

O reconhecimento da dimensão ética no aprendizado da Biologia é abordado por alguns autores. Ferraz (1997), a partir da análise da proposta curricular do ensino de Biologia no Estado de São Paulo, destaca a importância da abordagem Bioética no ensino de Biologia no currículo do Ensino Médio. A autora aponta que tal abordagem, inserida no currículo, tem um importante papel na contribuição da Biologia para o exercício da cidadania, possibilitando, assim, uma postura mais crítica no mundo. Oliveira (1997), uma das pioneiras nesta preocupação, defende a inserção da Bioética no Ensino Médio, pois, muitos terminarão seus estudos nesse nível de ensino. É também nesse estágio que se encontram jovens com certa maturidade, a quem o conhecimento adquirido pela Biologia proporciona capacidade de decisão, despertando, assim, uma consciência crítica, uma consciência Bioética que priorize o resgate da função social das ciências biológicas (OLIVEIRA, 1997).

Em um interessante levantamento realizado por Razera e Nardi (2006), sobre as recentes publicações de pesquisas em ensino de Ciências no Brasil, nitidamente se percebe a ausência da temática da ética e dos valores. Os autores revelam que há uma valorização de aspectos cognitivos referentes à construção e ao desenvolvimento do conhecimento, caracterizada por um grande volume de trabalhos publicados sobre temas vinculados ao ensino, currículo e formação de professores. Por outro lado, outros assuntos são negligenciados ou omiti- 
Bioética e ensino de Ciências: o tratamento ...

dos no conjunto das investigações da área, entre eles, assuntos relacionados à construção e evolução da moral do aluno. O quadro se mostra insatisfatório na medida em que a área de Ciências e, especificamente, Biologia, trazem cada vez mais implicações éticas profundas para a sociedade.

\section{Possíveis relações entre tecnociência e sociedade}

A maioria dos temas bioéticos encontram-se na relação que a Ciência estabelece com a Sociedade. Uma forma de identificação dessa relação foi proposta por Habermas (2001). O autor classifica essa relação em três grupos: as interações tecnocráticas, as decisionistas e as pragmático-políticas.

No modelo tecnocrático na organização da sociedade, há uma tendência a se recorrer aos especialistas para que tomem decisões neutras, puramente ditadas pela racionalidade científica. Neste modelo, os especialistas ou cientistas determinariam as políticas a serem seguidas, isto é, a população delegará, a eles, a decisão. Tal postura é bem difundida em nossa sociedade, evidenciada no discurso de muitos, que depositam, na Ciência, uma real esperança para a solução dos problemas da humanidade. Na escola, essa postura é observada e potencializada quando alunos depõem ou comentam notícias relacionadas ao desenvolvimento científico ou aos produtos da ciência (SILVA, 2002). Um estudo realizado pelo autor apontou que muitos estudantes dão credibilidade ao fazer científico, considerando uma perspectiva linear da produção científica e tecnológica para um futuro melhor que o presente. Krasilchik (1996) menciona que isto é decorrência da apresentação da Biologia nas escolas de Ensino Fundamental e Médio, que ainda refletem o momento histórico do grande desenvolvimento científico das décadas de 1950 e 1960.

O modelo decisionista distingue entre os fins e os meios, os fins ou objetivos devem ser determinados por decisões livres, de maneira independente da ciência, enquanto os meios seriam determinados pelos especialistas. Faz, portanto, uma distinção entre tomadores de decisão e técnicos. Uns determinam os fins, outros, os meios, o que diminui a dependência em relação ao técnico, uma vez que são as próprias pessoas que decidem sobre os seus objetivos. "Uma sociedade decisionista considerará que cabe às instituições políticas determinar os objetivos visados por esta sociedade. [...] O lugar da racionalidade seria então a determinação dos meios, a determinação dos fins, da esfera de pura liberdade" (FOUREZ, 1995, p. 209-10).

Por último, no modelo pragmático-político de interação entre a Sociedade e a Ciência, o que é privilegiada é a perpétua discussão e negociação existente entre o 'técnico' e os 'não especialistas'. Pressupõe um debate permanente entre tais esferas, no qual os conhecimentos e as negociações sociopolíticas entram em consideração. Este modelo insiste no fato de que os meios escolhidos podem alterar os objetivos ${ }^{3}$, remetendo-se, assim, às negociações, motivo pelo qual é denominado, além de pragmático, também político. Por fim, este modelo de inte-

\footnotetext{
${ }^{3}$ Morin (2005, p. 128) vai denominar esta possibilidade como "ignorância da ecologia da ação", onde "toda ação humana, a partir do momento em que é iniciada, escapa das mãos do seu iniciador e entram em jogo as múltiplas interações próprias da sociedade, que a desviam do seu objetivo e às vezes lhe dão um destino oposto ao que era buscado inicialmente".
} 
ração entre a Ciência e a Sociedade é o que cria condições para exercício da cidadania, à medida que abre um espaço permanente de discussão, debate e reflexão, e que, para tanto, incumbe seus cidadãos para frequentes tomadas de decisões bem como o desenvolvimento de atitudes e valores que tais situações lhes exigem.

A escola tem um importante papel neste contexto. Sobre o currículo de Biologia, Krasilchik (1996) aponta que, ao longo dos últimos anos, a grande maioria dos programas de Biologia, no Ensino Médio - fato verificado até início dos anos 1990 - indica a falta de análise das implicações sociais do desenvolvimento científico e tecnológico, tão presente nos meios de comunicação. $\mathrm{O}$ exame das propostas curriculares mostra que o conceito de Biologia como Ciência só aparece em 50\% dos programas. A relação CTS (Ciência/Tecnologia/Sociedade) aparece ainda menos, indicando necessidade de se considerarem as implicações sociais do desenvolvimento científico e tecnológico.

A autora afirma que muitos educadores admitem que a Biologia, além das funções que desempenha no currículo escolar, deve passar a ter outra, preparando os jovens para enfrentarem e resolverem problemas sociais e individuais, alguns dos quais com nítidos componentes biológicos, e analisarem as implicações sociais da Ciência e da Tecnologia.

Neste texto pretendemos destacar alguns aspectos que servem de base para a análise de dados que obtivemos, e convergir para o conceito de cidadania, que deve permear toda proposta educativa.

Canivez (1991) propõe uma forma de educação que convém às democracias para contemplar uma escola que realmente forme o cidadão. Esta democracia lhes pede uma forma de moralidade que o século XVIII designava de virtude, dando, aos indivíduos, a possibilidade de se humanizarem ao aprenderem a constituir uma verdadeira comunidade, fundamentada na recusa à violência e ao arbítrio, na liberdade reconhecida e garantida a cada um pelo direito. $\mathrm{O}$ autor acrescenta que a cidadania ativa repousa em uma educação da faculdade de julgar, considerando dois tipos de juízo. De um lado, considera o juízo crítico - este tem seus critérios definidos pela lei fundamental que é a Constituição, e, além disso, pelos direitos humanos fundados no respeito à pessoa. Por outro lado, considera o juízo político - este deve ir além da mera crítica, mas deve, também, considerar soluções possíveis, imaginar o que convém fazer para decidir, seja para propor, seja para negar, seja para aprovar.

A educação para uma cidadania ativa, no exercício de participação e desenvolvimento da argumentação, deve oferecer as condições para que os estudantes tenham, como dito nas palavras de Canivez (1991, p. 164), o "gosto e o hábito da discussão", fato este não observado nos cursos de ciências, como apontado por Bryce e Gray (2004). Os autores, em recente estudo, destacaram as dificuldades que os professores têm em lidar com questões controversas. As justificativas vão desde a falta de tempo; o desconforto em se expor; o medo em não apresentar os fatos, mas apenas suas opiniões; dificuldade em lidar com discussões; o interesse em apenas ensinar ciências, deixando, para as ciências sociais, as habilidades de discussão. O estudo fez também um relato das percepções dos estudantes quanto às controvérsias. Estes são unânimes em apontar que as discussões, quando ocorrem nas aulas, são provocadas ou iniciadas pelos alunos, em razão de algo que leem ou ouvem, e, raramente ou ocasionalmente, provocada pelos professores. $\mathrm{Na}$ visão dos estudantes, os professores, nas discussões, são sempre neutros. Para eles, a discussão é como um apêndice da aula, e nunca integrada à mesma. Importante ressaltar que, a despeito das dificuldades, o estudo mostra que, tanto professores quanto os alunos 
Bioética e ensino de Ciências: o tratamento ...

consideram essencial e valiosa a discussão dos aspectos éticos e sociais no ensino de ciências, sobretudo aqueles apresentados pela biotecnologia (BRYCE; GRAY, 2004).

\section{Bioética}

Convém reiterar que a Bioética, pelo seu caráter interdisciplinar, pode se tornar um rico instrumento metodológico no ensino das disciplinas científicas, pois assenta-se sobre um original saber transdisciplinar.

Uma das perspectivas bioéticas que adotamos é a Bioética de proteção, que se vale do conceito de vulnerabilidade, remetido ao contexto de uma sociedade que consome os produtos da biotecnociência, a um público mal orientado, em se tratando, sobretudo, do contexto brasileiro onde há um baixo nível educacional. Por que a vulnerabilidade constitui uma preocupação da Bioética? Uma resposta simples é a de que indivíduos e grupos estão sujeitos à exploração, e esta é moralmente errada.

Kottow (2003) destaca que a vulnerabilidade intrínseca da existência humana é, até certo ponto, protegida pela sociedade. Esta vulnerabilidade reconhecida e protegida por um Estado mínimo costuma ser aceita por todas as concepções políticas e considera que todos os integrantes e cidadãos da nação são igualmente vulneráveis, consequentemente a proteção dessa modalidade de vulnerabilidade tem por inspiração o princípio da justiça. Por outro lado, o mesmo autor vai afirmar a existência de uma vulnerabilidade circunstancial ou secundária. decorrente da pobreza, da falta de acesso à educação, das doenças e da discriminação. A forma derivada de ser vulnerável, neste caso, é, na verdade, um estado de predisposição a sofrer mais danos.

Num baixo quadro econômico e social, evidencia-se, também, um baixo status econômico e social dos estudantes limitando seu poder de negociação e discussão, o que, consequentemente, aumenta a sua vulnerabilidade. É oportuno questionar se a educação científica tem minimizado tal vulnerabilidade circunstancial.

\section{Bioética, Ensino de Ciências e Biologia}

Sobre a educação em Bioética, Martins (2000) enfatiza a pertinência da sua inserção no contexto brasileiro:

[...] o ensino de bioética precisa fundamentar-se na profunda visão dos valores dominantes. [...] Valores estes que priorizarão princípios como dignidade, liberdade moral, respeito por todas as formas de vida, vulnerabilidade, integridade, solidariedade, equidade e outros. [...] (MARTINS, 2000, p. 208)

Sgreccia (2000) alerta sobre a urgência de um programa bioético ou de uma Bioética que permeie os programas educativos:

A partir do momento em que a tutela da vida e da saúde depende em grande parte do comportamento dos indivíduos e não somente da 
Silva, P. F.; Krasilchik, M.

medicina e da economia, torna-se urgente uma transição da informação e da formação bioética no âmbito da educação, na família, na escola e nas chamadas agências educativas, ali compreendidos os meios de comunicação social. (SGRECCIA, 2000, p. 18)

A partir de uma pedagogia problematizadora, a Bioética torna-se um importante instrumento de ensino-aprendizagem. Neste ponto, configuram-se, atualmente, temas para reflexão, tais como: contracepção, novas tecnologias reprodutivas, as manipulações genéticas, a sexualidade, o acesso aos meios de manutenção da saúde, alimentos transgênicos, questões voltadas ao meio ambiente (poluição, redução de recursos energéticos, consumismo). Alguns autores reivindicam que a reflexão da bioética, a partir dos países em desenvolvimento, implicaria saber o que significa viver nesta realidade, onde vida e morte estão constantemente presentes de forma paradoxal (PESSINI; BARCHIFONTAINE, 1991). Assim, algumas questões poderiam ser tematizadas, tais como: desnutrição, doenças, desemprego, carência cultural e discriminação. A Bioética, neste caso, tem o desafio de ultrapassar a dimensão biológica e resgatar a visão biossociológica, questionando os altos investimentos da biotecnologia, pois, suas conquistas estão reservadas a poucos.

Uma proposta de ensino de Bioética, voltada especificamente para estudantes do final do Ensino Fundamental e Ensino Médio, é oferecida por Bishop (2006). Ela aponta que os objetivos da aprendizagem e do ensino da bioética seriam, entre outros: desenvolver a percepção ética e as habilidades de raciocínio analítico, adquirir um senso de responsabilidade pessoal e lidar com a ambiguidade moral. O sucesso dessa abordagem depende do preparo cuidadoso da aula e um certo background por parte do professor, para que possa guiar a discussão da classe de maneira que os alunos sejam levados a descobrir e expressar as questões de valores por si mesmos, e a pensar a respeito dos prós e contras diante de uma situação. A autora propõe uma forma de apresentar os dilemas bioéticos a partir de estudos de casos. Neles, os dilemas apresentados podem fazer uma ponte entre as dúvidas da vida real e os fatos da ciência. Assim, os alunos desenvolvem habilidades analíticas, aumentam sua criticidade, praticam sua expressão e capacidade de ouvir. Os casos devem ser atraentes, ou por serem verdadeiros ou porque cada caso é único e as soluções não têm fórmulas. A sua análise aponta também para sua complexidade, mobilizando conteúdos de ordem conceitual, procedimental e atitudinal (BISHOP, 1999).

A tematização dos valores na educação, especificamente no ensino de ciências e biologia, e sua consequente contribuição na formação ético-moral do estudante levou-nos à literatura voltada à educação ético-moral na perspectiva filosófica e psicológica. Ambas perspectivas destacam o conceito de autonomia moral, não explorado aqui devido aos limites do presente texto.

Na perspectiva filosófica, Rousseau (2004) destaca que o estágio de autonomia moral se atinge na educação para a razão. Ao seu lado, Kant (1996) afirma que a educação tem um caráter efetivamente formativo, cuidando-se da moralização. Na perspectiva psicológica, temos Piaget $(1994,1996)$, que forneceu as explicações sobre o desenvolvimento da consciência moral, ou julgamento moral na busca da autonomia moral, partindo-se de um estágio heterônomo (PIAGET, 1994). Kohlberg (1984) dá continuidade aos trabalhos de Piaget tendo como foco não mais indivíduos infantis, mas debruçando-se na sistematização de estágios nos níveis 
Bioética e ensino de Ciências: o tratamento ...

pré-convencionais, convencionais e pós-convencionais, em adolescentes e adultos. É importante ressaltar que Piaget e Kohlberg trabalharam para resgatar a noção do indivíduo moralmente consciente, dotado de razão e responsável por seus julgamentos e atos.

\section{Objetivos}

O presente estudo é parte integrante de uma pesquisa mais ampla, desenvolvida em tese de doutorado que teve como objetivo: analisar se a formação inicial de professores de Ciências e Biologia tem contribuído para a tematização e construção de valores, e verificar, sob a ótica dos licenciandos, seu papel na formação ético-moral dos futuros estudantes e seu nível de preocupação sobre a dimensão ética dos saberes científicos e tecnológicos (SILVA, 2008). Especificamente neste texto, analisamos como os licenciandos identificam e lidam com temas controversos, que, potencialmente, poderiam ser discutidos com seus futuros alunos, sobretudo, a abordagem metodológica a ser utilizada no tratamento de tais temas.

\section{Procedimentos metodológicos}

O percurso metodológico do presente estudo descritivo-explicativo caracterizou-se pelo uso de um questionário com quatro questões abertas, correspondentes a quatro casos aplicados a 32 licenciandos, pertencentes a três Instituições de Ensino Superior do município de São Paulo. Todos os licenciandos foram voluntários e se dispuseram a colaborar mediante assinatura do termo de consentimento livre e esclarecido. Vale destacar que esses 32 sujeitos eram pertencentes aos 106 participantes da pesquisa da primeira fase do estudo amplo, não descrito aqui (SILVA, 2008).

Os casos mencionados apresentavam conteúdos com dilemas éticos e envolviam questões ligadas ao meio ambiente, ao uso das novas biotecnologias, e à relação entre ciência e sociedade, inclusive como estudantes do Ensino Médio se posicionavam em relação a algumas delas (SILVA, 2002, 2008). Inicialmente, perguntava-se objetivamente, ao sujeito, se o mesmo identificava, ou não, algum conflito ético na situação relatada. Se a resposta fosse positiva, o licenciando devia elaborar duas questões que explicitassem os conflitos e como trataria metodologicamente o tema em sala de aula.

A análise de conteúdo, descrita por Gomes (1993), foi aqui adotada. Para este autor, na Análise de Conteúdo - compreendida, hoje, muito mais como um conjunto de técnicas inicialmente, predominava o aspecto quantitativo, geralmente traduzido pela contagem da frequência da aparição de características nos conteúdos das mensagens veiculadas. Uma de suas funções, citada pelo autor, e que esta pesquisa utilizou, é a "descoberta do que está por trás dos conteúdos manifestos” (GOMES, 1993, p. 74), indo além das aparências do que está sendo comunicado. As opiniões do sujeito não são aleatórias, mas influenciadas por sua concepção de mundo, consciente ou não. Desta forma, parte-se da descrição dos conteúdos manifestos, as respostas às questões abertas, para, através da discussão com a literatura, interpretá-las.

Seguem breve descrição e análise das percepções dos licenciandos sobre cada caso. 
Silva, P. F.; Krasilchik, M.

\section{Caso 1}

Numa aula de ecologia, um aluno menciona uma propaganda que alegava melhores qualidades nas sementes transgênicas, aumentando a produtividade e diminuindo os custos de produção. Outra aluna apontou para os riscos potenciais, nos ecossistemas e na saúde humana, das sementes transgênicas, ressaltou, ainda, que não há a devida rotulagem dos produtos que contêm transgênicos informando o consumidor. Um terceiro aluno lembrou-se da invasão, de um grupo de mulheres, num laboratório de pesquisas com sementes transgênicas, destruindo-o. Alegavam as más consequências sociais e ambientais do avanço da invasão do deserto verde criado pelo monocultivo de eucaliptos. Pesquisas de vários anos e outras em andamento foram interrompidas.

Ao explicitarem os conflitos presentes neste caso, os sujeitos, de forma predominante, reprovam a atitude das mulheres, defendem o não-uso da violência e apontam para formas mais democráticas para a resolução de conflitos. Outro aspecto destacado foi a falta de rotulagem dos produtos transgênicos, que, de certa forma, afeta a autonomia do sujeito, isto é, sua escolha diante do produto.

\section{Caso 2}

Caso Roberta Jamilly. A saliva deixada por Roberta Jamilly Martins em um cigarro fumado por ela na delegacia de Goiânia foi o material necessário para a realização de exame de DNA. O resultado prova que Roberta é, na verdade, Aparecida Fernanda Ribeiro da Silva, recém-nascida roubada numa maternidade de Goiânia aos dois dias de vida, em março de 1979. Diante da recusa de Roberta de fazer o exame de DNA, a perita criminal de Goiás sugeriu colher material sem que Roberta soubesse. Quando estava sendo ouvida pelo delegado, Roberta pediu para sair e fumar no corredor. Um agente recolheu a ponta do cigarro no cinzeiro e guardou-a num saco de papel. O material foi enviado à Divisão de Pesquisa de DNA Forense da Polícia Civil de Brasília. O delegado disse que a forma como foi recolhido o material para a realização do exame de DNA é totalmente legal, e que o material usado para fazer o DNA é descartável, ou seja, já havia sido utilizado por ela, que o jogou fora. Não houve nenhuma invasão de privacidade.

Grande parte das respostas dos sujeitos, neste caso, envolvia aspectos da falta de consentimento informado de Roberta e sua invasão de privacidade, consequentemente falta de autonomia. Destacou-se o conceito de alteridade, que foi mencionado em grande parte das respostas dos sujeitos, tanto em relação a Roberta ou, mesmo, em relação à mãe biológica.

\section{Caso 3}

Limites da atividade científica. Um levantamento realizado junto a estudantes ingressantes no Ensino Médio, quando questionados sobre quem deve estabelecer limites para a atividade científica, apontou que:

- 54\% dos estudantes creem que toda a sociedade deve estabelecer limites para a atividade científica; 
Bioética e ensino de Ciências: o tratamento ...

- 38\% dos estudantes creem que apenas os cientistas devem estabelecer limites para a atividade científica;

- $8 \%$ não responderam.

A maioria dos licenciandos questionou se a sociedade está realmente capacitada ou informada para estabelecer tais limites, em outras palavras, se o seu nível de compreensão a credencia para isso. Outra justificativa que se alinha nesta perspectiva questiona que motivo tem a sociedade para se importar com assuntos científicos, pois ela seria leiga nos assuntos científicos.

\section{Caso 4}

Áreas de preservação ecológica versus soberania geopolítica. Em um levantamento realizado junto a estudantes do Ensino Médio, quando questionados sobre a responsabilidade da preservação ambiental de regiões com grande biodiversidade (por exemplo, a região amazônica), apontou o seguinte:

- 29\% dos estudantes creem que a responsabilidade é apenas dos países onde estas áreas estão;

- 68\% dos estudantes creem que a responsabilidade é também de outros países;

- 3\% não responderam.

Os licenciandos, em sua maioria, apontaram a importância da preservação da biodiversidade. Há um enfoque sobre soberania versus responsabilidade, e, neste aspecto, destacam: se a Amazônia fosse patrimônio da humanidade em que medida a soberania geopolítica do país seria afetada? Neste aspecto, levantam os conflitos de interesse entre países onde estas áreas estão com outros que não detêm essas áreas, bem como se tais países teriam condições de cuidar destas áreas e se receberiam ajuda financeira.

\section{Resultados e análise}

Os licenciandos admitem que a formação ético-moral é fundamental para a formação do estudante; creem que a escola, bem como outros ambientes sociais vinculados ao estudante são corresponsáveis por esta formação. Para eles, há uma concordância que estudantes do Ensino Fundamental e Médio estejam em pleno desenvolvimento de sua personalidade moral, além disso, acrescentam o importante papel da disciplina de Ciências e Biologia como espaço de promoção de valores éticos-morais. Essa caracterização foi possível traçar a partir da análise de algumas questões obtidas na primeira fase da pesquisa.

Todos os licenciandos identificaram algum conflito ético na situação relatada.

O tratamento que os licenciandos dariam ao tema em classe é explicitado no Quadro 1. A primeira coluna revela os procedimentos metodológicos recomendados pelos sujeitos em cada caso. As respostas relativas a cada caso são apresentadas de forma a permitir uma comparação entre eles. Os dados são apresentados com suas frequências relativas, expressos em números absolutos equivalentes ao número dos sujeitos. 
Silva, P. F.; Krasilchik, M.

Quadro 1. Recursos metodológicos sugeridos pelos licenciandos no tratamento dos casos.

\begin{tabular}{|l|c|c|c|c|}
\hline \multicolumn{1}{|c|}{ Recursos metodológicos } & Caso 1 & Caso 2 & Caso 3 & Caso 4 \\
\hline Exposição do professor & 14 & 16 & 18 & 15 \\
\hline Debate (prós e contras) & 5 & 5 & 4 & 3 \\
\hline Discussão (prós e contras) & 1 & 6 & 1 & 6 \\
\hline Problematização & 4 & 1 & 4 & 1 \\
\hline Trabalho de consulta escolar & 4 & 2 & 1 & 1 \\
\hline Uso de artigos de jornais & 2 & & 1 & 2 \\
\hline Estudo de caso & 1 & 1 & 1 & 2 \\
\hline Simulação-(role play) & & 1 & 2 & \\
\hline Exposição de convidados & & & & 1 \\
\hline Uso de artigos científicos & 1 & & & \\
\hline Seminário & & & & 1 \\
\hline
\end{tabular}

Fonte: Silva (2008).

Ao se tratar o caso em classe, verificou-se que metade dos licenciandos aponta a exposição do professor como abordagem metodológica prioritária. Tal exposição refere às informações dos prós e contras da situação apresentada, como, também, à apresentação dos temas relacionados. Nela, o tratamento de tais questões seria restrito a uma simples aula expositiva. Assim, o professor ainda exerce um papel central como expositor do assunto. Há pouca oportunidade de conversação para que os estudantes em grupo e de forma cooperativa discutam os temas. Há um destaque aos conteúdos conceituais envolvidos no fato em detrimento dos conteúdos procedimentais e atitudinais apresentados na exposição do professor, reforçando-se o ensino de ciências num modelo tecnocrático de relação entre Ciência e Sociedade (HABERMAS, 2001).

Outra forma mencionada pelos licenciandos no tratamento do tema foi o debate e a discussão. Interessante notar que os mesmos são tratados como sinônimos. Infelizmente, a maioria não explicita os passos para inseri-los, isto é, como desencadearia os mesmos, reconhecendo-se, assim, o uso genérico desses termos sem pretensões efetivamente metodológicas. Em outras palavras, não há informações de como desencadear o debate e a discussão, mas, apenas, o que tematizar, tais como: menção dos prós e contras da situação, benefícios da preservação, consequências do desmatamento, biopirataria, patentes, atuação de ONGs, exame de DNA e privacidade, entre outros. Além disso, alguns apontam o importante papel do professor como mediador. Muito embora mencionado, o gosto e o hábito da discussão estão longe de fazer parte do cotidiano escolar (BRYCE; GRAY, 2004; CANIVEZ, 1991).

Outra abordagem metodológica apontada pelos licenciandos foi a problematização. Neste caso, trata-se da elaboração de uma questão para inserção do problema, devendo esta ser motivadora para desencadear a conversa entre os alunos. Poucos sujeitos a exemplificaram, alguns licenciandos apontaram certas estratégias para essa problematização: o trabalho em grupo, a discussão interna e a discussão com a classe toda, a sensibilização, a partir de leituras paradidáticas, e visitas à turma de pesquisador ou integrante de comitê de ética foram estratégias também mencionadas. 
Bioética e ensino de Ciências: o tratamento ...

Comparando os dados apresentados no quadro, percebe-se que os casos 1 e $3 ; 2$ e 4 no que se refere à discussão e problematização, respectivamente, apresentam os mesmos resultados (Quadro 1, itens discussão e problematização); em outras palavras, ao mesmo tempo em que os casos 1 e 3 fornecem base para desencadear problemas, os mesmos licenciandos sentem-se menos à vontade para discuti-los (prós e contras), talvez por receio de envolvimento em questões políticas. A interpretação pode revelar o receio de discussões políticas ou falta de informação que os casos 1 e 3 exigiriam para uma adequada discussão. Importante mencionar que os casos 2 e 4 são mais permeáveis às discussões, talvez por fornecerem, na percepção dos licenciandos, elementos mais claros para fazê-los.

Outro procedimento sugerido por um número pequeno de sujeitos foi o trabalho de consulta escolar. Apenas uma abordagem metodológica foi destacada por explicitar os passos e o objetivo dessa consulta. Primeiro passo, seleção do tema - preservação da Amazônia -; segundo passo, responder às perguntas: por quê, e para quem?, numa abordagem interdisciplinar e, posteriormente, preparar exposição na escola.

O uso de notícias de jornais para tratar, em classe, esses conflitos foi mencionado por poucos sujeitos. Sabemos do potencial dessa rica ferramenta metodológica para tratar assuntos controvertidos (SILVA, 2002). Um licenciado sugeriu a confecção de um painel decorrente das discussões em torno de tais notícias. Pode-se atribuir um significado grande para este recurso metodológico, pois, a sala de aula deve tornar-se permeável ao cotidiano, constituindo-se, assim, um bom recurso metodológico para o ensino de Ciências.

Alguns poucos licenciandos apontaram a encenação como recurso para discussão, utilizando a troca ou uso de papéis, role play - novamente, a explicitação de tal abordagem foi mencionada por poucos sujeitos. Alguns apontaram a importância de um diagnóstico junto aos alunos para, em seguida, por exemplo, montar uma encenação dos 'diferentes lados'.

Chamou-nos a atenção a simulação descrita por um dos sujeitos, sobre o caso 3:

- os alunos sozinhos decidiriam "como seria a escola" - discussão;

- (role play) um grupo pequeno (cientistas) e outro grupo maior (sociedade);

- O grupo pequeno defenderia que só eles deveriam tomar decisão, e o outro grupo ao contrário.

Vale destacar que o trabalho em grupo, a interação grupal, forte componente para o desenvolvimento da autonomia moral e intelectual (KOHLBERG, 1984; PIAGET, 1996), não está tão presente nas propostas metodológicas sugeridas pelos licenciandos.

Palestras, seminários, estudo e análise de casos, ensino sobre reciclagem, trabalho interdisciplinar e uso de analogias foram também recursos metodológicos mencionados, sem especificar como construí-los ou desencadeá-los.

\section{Considerações finais}

De maneira geral, os dados, organizados no quadro, permitiram demonstrar que os licenciandos têm sensibilidade aos temas e conseguem, inclusive, perceber conflitos éticos, problematizando-os. Por outro lado, faltam estratégias de como abordá-los com seus alunos. Percebe-se, nas observações dos licenciandos, que o professor tem ainda um papel central, muitas vezes não como mediador de uma discussão, mas como expositor dos temas, inclusive 
Silva, P. F.; Krasilchik, M.

dos dilemas, pois os conhecimentos (conteúdos conceituais) fornecem uma base segura para o trabalho do professor. Neste aspecto, a formação inicial tem dado pouca contribuição aos professores para lidarem com estratégias que requeiram, destes, exercícios de tomada de posição e o convívio com a divergência.

Apesar de todos os licenciandos identificarem os conflitos presentes nos casos mencionados, isto não foi suficientemente capaz de gerar formas metodológicas de abordá-los em sala de aula. Esse 'descolamento' permite-nos inferir que pouca atenção tem sido dispensada aos procedimentos de educação ético-moral, durante a formação do licenciando.

Interessante notar que alguns licenciandos mencionam a importância de se chegar a uma conclusão, expressando, assim, uma tentativa de se chegar a um consenso das opiniões 'em nome' dos aspectos científicos, numa postura 'cientificista' das questões, onde a "voz da ciência", revestida de autoridade, seria o ponto de convergência e conclusão, evidenciando-se o modelo tecnocrático (HABERMAS, 2001) já descrito:

Sujeito 47 IES II (grifo nosso): Tentar buscar diversas fontes sobre o mesmo assunto. Tentar identificar o conbecimento prévio dos alunos. Tentar identificar fontes mais seguras de fontes menos seguras para tentar junto com a sala discutir o assunto e, tentar entrar em um conceito único e explicando conceitos biológicos.

Em outras palavras, busca-se uma conclusão em assuntos inconclusivos e uma simplificação em assuntos de natureza complexa. Uma das características da metodologia da discussão ou do debate é a 'convivência' com a controvérsia. Houve menção de um certo medo da discussão, evitando-se o conflito, pelas razões apontadas na literatura (BRYCE; GRAY, 2004; KRASILCHIK; MARANDINO, 2007). Assim, pouca atenção tem sido dada a este aspecto na formação do professor, isto é, lidar com a divergência.

Jennings et al. (1991) destacam que os professores devem ter em mente os objetivos gerais da educação em valores e, assim, lidar com a ambiguidade moral. Neste sentido, destacam que devemos aprender a tolerar discordâncias e aceitar as ambiguidades inevitáveis que surgem ao examinarmos problemas éticos. Acrescentam que muitas questões éticas não chegam a um resultado claro e definitivo.

É perfeitamente normal e inevitável sentir desconforto com uma questão ética e com os desafios especiais em lidar com tais valores. Assim, essa insegurança dos professores de Ciências em lidar com a controvérsia leva-os a adotar uma posição de neutralidade para trazer segurança (BRYCE; GRAY, 2004). Por outro lado, uma discussão de valores, para ser bemsucedida, reside na capacidade do professor em conduzir a discussão e na curiosidade e envolvimento dos alunos. Esses têm a oportunidade de contatar ideias pouco familiares e aprender a perceber conexões entre decisões, ações e suas consequências para si, para os outros e para o conjunto da sociedade. Nessa tarefa, algumas características são requeridas do professor, tais como: maturidade de julgamento, razão lógica e habilidades analíticas, domínio do assunto científico, entre outras, que proporcionam as ferramentas necessárias para lidar com questões éticas de uma maneira construtiva, sobretudo, considerando o outro.

Enfim, tais assuntos deveriam fazer parte obrigatória do repertório da formação inicial de professores de Ciências e Biologia, de modo que estejam preparados para tratá-los de forma adequada e criativa em suas atividades com os alunos. 
Bioética e ensino de Ciências: o tratamento ...

\section{Referências}

BISHOP, L. High school bioethics curriculum project. Washington : Kennedy Institute of Ethics, 1999. Disponível em: < http://www3.georgetown.edu/research/nrcbl/ hsbioethics/index.html>. Acesso em: 06 maio 2005.

Teaching bioethics in high school: an American experience - the high school bioethics curriculum project at the Kennedy Institute of Ethics. In: SEMINÁRIO NACIONAL DO CONSELHO NACIONAL DE ÉTICA PARA AS CIÊNCIAS DA VIDA, 9., 2005, Lisboa. Actas... Lisboa: Fundação Calouste Gulbenkian, 2006. p. 17-30.

BRYCE, T.; GRAY, D. Tough acts to follow: the challenges to science teachers presented by biotechnological progress. International Journal of Science Education, Abingdon, v. 26, n. 6, p.717-733, 2004.

CANIVEZ, P. Educar o cidadão? Campinas: Papirus, 1991.

FERRAZ, C. A. A abordagem das questões bioéticas no ensino de biologia de $2^{\circ}$ grau. 1997. 150 f. Dissertação (Mestrado em Educação) - Pontifícia Universidade Católica, São Paulo, 1997.

FOUREZ, G. A construção das ciências: introdução à filosofia e a ética das ciências. São Paulo: Editora da Unesp, 1995.

GOMES, R. A análise de dados em pesquisa qualitativa. In: MINAYO, M. C. S. Pesquisa social: teoria, método e criatividade. Rio de Janeiro: Vozes, 1993. p. 67-80.

HABERMAS, J. Técnica e ciência como ideologia. Lisboa: Edições 70, 2001.

JENNINGS, B. et al. New choices, new responsibilities: ethical issues in the life sciences: a teaching resource on bioethics for high school biology courses. Garrison: Hastings Center, 1991.

KANT, I. Sobre a pedagogia. Piracicaba: Ed. Unimep, 1996.

KOHLBERG, L. The psychology of moral development: essays on moral development. New York: Harper \& Row, 1984.

KOTTOW, M. H. Comentários sobre bioética, vulnerabilidade e proteção. In: GARRAFA, V.; PESSINI, L. (Org.). Bioética: poder e injustiça. São Paulo: Loyola: Sociedade Brasileira de Bioética, 2003. p. 71-78.

KRASILCHIK, M. Prática de ensino de biologia. 3. ed. São Paulo: Harbra, 1996.

KRASILCHIK, M.; MARANDINO, M. Ensino de ciências e cidadania. São Paulo: Moderna, 2007.

MARTINS, M. V. A. A pertinência da bioética para educação num mundo globalizado. In: SIQUEIRA, J. E.; PROTA, L.; ZANCANARO, L. (Org.). Bioética: estudos e reflexões. Londrina: Ed. da UEL, 2000. p. 205-220.

MORIN, E. Ciência com consciência. Rio de Janeiro: Bertrand Brasil, 2005. 
Silva, P. F.; Krasilchik, M.

OLIVEIRA, F. Bioética: uma face da cidadania. São Paulo: Moderna, 1997.

PESSINI, L.; BARCHIFONTAINE, C. P. Problemas atuais de bioética. São Paulo: Loyola, 1991.

PIAGET, J. O juízo moral na criança. São Paulo: Summus, 1994.

Os procedimentos em educação moral. In: MACEDO, L. (Org.). Cinco estudos de educação moral. São Paulo: Casa do Psicólogo, 1996. p. 1-36.

RAZERA J. C. C.; NARDI, R. Ética no ensino de ciências: responsabilidades e compromissos com a evolução moral da criança nas discussões de assuntos controvertidos. Investigações em Ensino de Ciências, Porto Alegre, v.11, n. 1, p. 53-66, 2006.

Disponível em: <http://www.if.ufrgs.br/ienci/main/artigos/ openAbstract.php?idArtigo=145 >. Acesso em: 15 mar. 2007.

REICH, W. T. Encyclopedia of bioethics. New York: Simon \& Schuster Macmillan, 1995.

ROUSSEAU, J. J. Emílio ou da educação. 3. ed. S. Paulo: Martins Fontes, 2004.

SGRECCIA, E. A bioética e o novo milênio. Bauru: EDUSC, 2000.

SILVA, P. F. Percepções dos alunos de ensino médio sobre questões bioéticas. 2002. 131 f. Dissertação (Mestrado) - Faculdade de Educação, Universidade de São Paulo, São Paulo, 2002.

Bioética e valores: um estudo sobre a formação de professores de ciências e biologia. 2008. 188 f. Tese (Doutorado) - Faculdade de Educação, Universidade de São Paulo, São Paulo, 2008.

Artigo recebido em 27/06/12. Aceito em 28/11/12. 